\title{
Wortels en agtergronde van Hervormde teologie en kerkwees in Suid-Afrika
}

\author{
D J C van Wyk (sr) \\ Tydelik-deeltydse dosent: Departement Godsdiens en Sendingwetenskap (Afd A)
}

Universiteit van Pretoria

\begin{abstract}
Roots and background of reformed theology and ecclesiastical being in South Africa

After investigating researches and publications on the ethical direction taken by Dutch theology in the late nineteenth and early twentieth centuries, $J$ A Loader came to the conclusion that this direction is an important - if not the most important - background to the theology of the Nederduitsch Hervormde Kerk van Afrika and of its theological training at the University of Pretoria, especially during the earlier years and at the time of its inception. In this article the outcome of the research undertaken by Loader is critically reviewed and seriously questioned. It is maintained that his evaluation of ethical theology is too rigid and its influence on the Nederduitsch Hervormde Kerk overemphasised. It seems that the prominent influence of Hoedemaker and confessional theology is overlooked by Loader.
\end{abstract}

\section{INLEIDING}

Om nog ' $n$ keer terug te kom op die saak van kerklike en veral teologiese eie-aardigheid van die Nederduitsch Hervormde Kerk en die agtergronde daarvan, is nie ' $n$ aanduiding dat dit van uitermate belang geag word nie. Immers, dit bly steeds baie belangriker om wat jy werklik is, te leef, as om daaroor te skryf en te praat. Veral vir 'n gelowige is dit belangrik om wat jy is, met soveel oortuiging en integriteit en tot so ' $n$ bekendheid uit te leef, dat jy dit nie in woorde hoef te formuleer of in konstruksies hoef uit te lê nie. Intussen bly dit interessant, vrugbaar en ook onafwendbaar om voortdurend antwoord te kry op die vraag: Wie is ek en waar kom ek vandaan? Dit geld van 'n indiwidu maar ook van die kerk en sy teologie.

Die terugskouing op vyf en sewentig jaar van formele Hervormde teologiese opleiding aan die Universiteit van Pretoria enkele jare gelede het groot dankbaarheid na vore gebring, maar het ook die gedagtes skerp geprikkel oor die agtergronde van 'n eie teologiese idioom in die algemeen en die teologiese opleiding in die besonder. Afgesien 
van omvattende navorsing oor die inhoud en koers van teologiese dosente se werk oor 'n driekwart eeu wat in die Hervormde Teologiese Studies neerslag gevind het, is daar ook in spesifieke bydraes gevra na die idioom van die Nederduitsch Hervormde Kerk en sy teologie. Van belang is veral bydraes van A D Pont, J P Oberholzer en J H Koekemoer waarop verderaan teruggekom word. Rautenbach het in dié verband altyd graag gepraat van Hervormde kerklike en teologiese geaardhede, geestesgesteldheid en verlangens. Daar kan nog bygevoeg word: eie Hervormde familietrekke. Hy, Rautenbach het natuurlik al in 1974 by die vyftigjarige fees van Van der Hoff Teologiese Vereniging indringend en meesterlk ' $n$ magdom insigte oor dié sake geboekstaaf (Rautenbach 1974:24-34).

Naas baie prikkelende fasette en nuanses van teologiebeoefening vanuit die Nederduitsch Hervormde Kerk wat tydens bogenoemde navorsing en skrywery aan die lig gekom het, is daar ook opnuut die besef van hoe moeilik dit is om dinge soos kerklike aard en teologiese idioom in formulerings saam te vat, veral nog as dit gaan om ' $n$ kerk en teologie wat kragtens sy aard steeks is om reglynige uitsprake oor die verhouding van God en mens te maak; ' $n$ teologie wat deurdronge is van die paradokse om vanuit die tyd oor die ewigheid te praat, om die onsêbare te moet sê.

Gunning (jr) het ' $n$ keer iets van hierdie Hervormde familietrek onder woorde gebring toe hy verantwoording moes aflê oor waarom hy en geesgenote in die Nederlandse Hervormde Kerk gebly het, ondanks al die verval.

Daarom verzeker $i k u$, dat van alle grondslagen mij als lid en voorganger meer dan ooit juist in die Hervormde kerkgemeenschap thuis gevoel. In een tijd, waarin, in het aangezicht van de steeds naderende Toekomst des Heren, meer en meer de voorlopigheid van alle dingen blijkt, gevoel $\mathbf{i k}$ mij in dié kerkgemeenskap (bij alle erkenning van haar ellende en al het schone en heerlijke buiten haar) het meest thuis, welke naar aard die voorlopigheid niet gelijk rondom haar doorgaans geschiedt, zelfgenoegzaam ontkent, maar in tegendeel haar tot beginsel verheft.

(Balke 1985:44)

Sit ' $n$ mens jou voet eenkeer op die pad om dié ondefinieerbare te probeer definieer, is dit noodsaaklik om deur middel van woord en weerwoord so breed en diep as moontlik te delf en te probeer deurvors. Want niemand wil graag self oor sy identiteit skewe of eensydige beelde verder in die geskiedenis afstuur nie. 


\section{LOADER SE WAARDERING VAN DIE ETIESE TEOLOGIE}

In dieselfde dankbare terugskouing en grawery na die wortels en agtergronde văn 'n eie Hervormde kerklike en teologiese etos en eie-aardigheid, het van die omvattendste en mees ontdekkende bydraes van Loader, tot onlangs verbonde as dosent aan die Fakulteit Teologie aan die Universiteit van Suid-Afrika en tans hoogleraar aan die Protestantse Teologiese Fakulteit van die Universiteit van Wenen, gekom. In 'n reeks bydraes kom hy na deeglike navorsing tot die bevinding dat die etiese rigting in die Nederlandse teologie van die laaste helfte van die negentiende en begin twintigste eeu, indien nie die belangrikste agtergrond nie, dan tog een van die belangrikste invloede in veral die vroeë stadium van 'n eie Hervormde teologiese opleiding in Suid-Afrika was.

In hierdie en 'n opvolgartikel word krities na dié bevinding van Loader gekyk. 'n Beskeie poging word aangewend om ten minste in die ruimte wat Loader self daarvoor laat, naas die etiese rigting, ook die invloed wat van die konfessionele rigting en dan veral Hoedemaker in die Nederlandse Hervormde Kerk op Hervormde teologie hier uitgegaan het, te suggereer. Maar daar sal verder gegaan word. Daar sal gepoog word om aan te toon dat die invloed vanuit die konfessionele rigting baie dieper, blywender en meer bepalend deurgewerk het in die Nederduitsch Hervormde Kerk as wat dit met die etiese rigting was. Daar sal gevra word of die etiese teologie uiteindelik enige blywende en beslissende invloed en merk hoegenaamd op ons eie teologiese denke kon gelaat het. Daar sal ingegaan word op die vraag of die gees wat die etiese teologie geadem het, werklik die is wat in die Hervormde Kerk hier in Suid-Afrika posgevat en voortgeleef het. Daar wil ook krities gevra word na Loader se verstaan en uitleg van die mees karakteristieke uitdrukking in die etiese teologie, naamlik die waarheid is eties, waaraan die rigting sy naam ontleen het. Daar sal uiteindelik tot die voorlopige bevinding gekom word dat Loader waarskynlik die invloed van die etiese rigting oorspan het.

Verderaan in hierdie artikel en in 'n opvolgartikel sal ook betoog word dat die ontwikkelingslyn wat Loader saam met ander tussen die etiese en die dialektiese teologieë meen waar te neem, nie houdbaar is nie; dat sterk kerklike verbondenheid juis nie 'n kenmerk van etiese teoloë was nie (met die uitsondering van J H Gunning jr en dan eers as ' $n$ baie laat ontwikkeling by hom in sy beïnvloeding deur en toenadering tot Hoedemaker); en dat piëtisme en bevindelikheid nie net 'n kenmerk van die meer evangeliese rigting in die etiese teologie was nie (Loader 1989:432), maar wel 'n hoofkenmerk wat die hele rigting deursuur het. Dié vrae en voorlopige bevinding wil graag vra vir navorsing en verdere besinning. Dit is noodsaaklik om seker te maak dat tot 'n ewewigte beeld oor ons teologiese verlede en hede gekom word. 
Tot dusver was daar slegs terloopse reaksies op Loader se standpunt. Pont (1994: 106) trek dit sterk in twyfel en stel dat daar in die teologiese opleiding beweeg is binne die bane van die Bybels-Reformatoriese teologie en dan wel in die rigting van die konfessionele teologie. Koekemoer (1994:22) aanvaar die mening van Loader oor die invloed van die etiese teologie maar stel dat daar ook sprake is van die invloed van 'n getemperde konfessionele teologie. Oberholzer (1992:578) erken dat Loader gewigtige argumente aanvoer vir 'n siening oor die invloed van die etiese teologie op die teologiese opleiding in Pretoria, maar wys dit as 'n leemte uit dat Loader die groot invloed van Hoedemaker in dié verband verbykyk. Nogtans aanvaar hy, in aansluiting by Loader, sterk invloed van die etiese teologie op onder andere Gemser. Breytenbach (1992:108) sluit by die gedagtegang van Loader aan en tipeer ook vir E S Mulder, 'n vroeëre hoogleraar in Ou-Testamentiese Wetenskap aan die Universiteit van Pretoria, as ' $n$ verteenwoordiger van die etiese rigting.

Loader het indringend ingegaan op die etiese rigting in die Nederlandse teologie. Sy siening oor dié invloed op die Hervormde Kerk en teologie alhier vind, soos hierbo aangetoon, reeds wye instemming en navolging, hoewel enkele kritiese vrae en opmerkings hier en daar nie ontbreek nie. Behalwe vir 'n doktorale proefskrif (1984) het hy ook in enkele artikels in die Hervormde Teologiese Studies op die etiese rigting, belangrikste verteenwoordigers en kenmerke asook verdere invloede daarvan ingegaan. Hierbenewens het hy die grondkonsepte van die etiese teologie alreeds volledig in vroeëre publikasies ontleed (Loader 1987:48).

Oor die invloed van die etiese teologie op die Hervormde Kerk en sy teologie haal ons samevattend veral uit genoemde drie artikels aan. Die kerntese van Loader (1987: 48 ) is dat die Hervormde tradisie in ons land al lank 'n derde opsie inneem tussen ortodoks-gereformeerd aan die een kant en liberaal-modernisties aan die ander kant. Die Hervormde teologie in Suid-Afrika is daarin diepgaande beïnloed deur die derde opsie (die etiese rigting) in die Nederlandse teologie wat vir die laaste helfte van die negentiende eeu en eerste helfte van die twintigste sterk waarneembaar was. Indirek het die invloed veral van teoloë soos Daniël Chantepie de la Saussaye, J H Gunning jr en H Th Obbink uitgegaan, direk deur jonger verteenwoordigers van dié rigting in Suid-Afrika self, waaronder Gemser en Van Selms.

Loader voer aan dat die term eties vir dié rigting nie 'sedelik' beteken soos daar al soms gedink is nie, maar dat die wese (ethos) van die waarheid vir dié teoloë in die sentrum van belangstelling staan. Soos by Daniël Chantepie de la Saussaye duidelik blyk, is die wese van die waarheid nie objektiveerbaar en rasionaliseerbaar nie. Nogtans kan die mens in aanraking daarmee kom. Die waarheid kan nie in 'n leer vasgevat 
en eties toegepas word nie want dit transendeer alle konsepte en proposisies wat gebruik kan word om dit uit te dra. Daar bestaan 'n affiniteit tussen God se selfbekendmaking en die menslike gees en daarom kan die mens wel weet van Hom en Hom ontmoet. Hierdie basiese oortuiging, sê Loader, is die hart van die etiese teologie en is op verskillende maniere uitgedruk deur verteenwoordigers van die vier generasies wat in hulle geledere onderskei kan word.

Verwant aan hierdie waarheidsopvatting is 'n volgende karaktertrek van die etiese teologie waarop Loader sterk klem lê, naamlik die handhawing van die reg om kritiese teologie en Skrifkritiek te beoefen. Aangesien die Goddelike waarheid slegs in 'n persoonlike ontmoeting wedervaar kan word, is die post-eventum-uitdrukking daarvan in menslike proposisies onvolkome en dus voorwerp van die kritiese wetenskap. Ook hierin het die etiese teologie 'n derde opsie tussen modernisme en ortodoksie ingeneem. Beide modernisme en ortodoksie het 'n proposisionele waarheidsbegrip gehandhaaf. Die waarheid is geleë in begrippe, konsepte, korrekte proposisies. Daarom is dié proposisies nie oop vir kritiese wetenskap nie.

In ' $n$ artikel oor die ontstaan en eerste periode van die Hervormde teologiese opleiding aan die Universiteit van Pretoria kom Loader (1989:412-437) tot die konklusie dat die Hervormde teologie soos bedryf aan die teologiese fakulteit (Afd A) te Pretoria, die karakter van die derde opsie in die Nederlandse teologie van dié tyd sou vertoon en dan meer bepaald dié van die etiese teologie. Hy voer aan dat vanaf die eerste inisiatiefnemers tot ' $n$ eie Hervormde teologiese opleiding in Suid-Afrika, soos Muller, Brandt, Van Belkum en andere, tot by die eerste fase dosente soos Greyvenstein, Engelbrecht, Gemser, Van Selms en Wolmarans, die invloed, agtergrond en atmosfeer van die etiese rigting onderskei en aangedui kan word. Dit het onder andere geblyk in 'n indringende kritiese sin, handhawing van sowel die historiese kritiek (teenoor die ortodoksie) as die kerklike belydenis (teenoor die vrysinnigheid), 'n aversie van dogmatisme, maar waardering vir kerklike verbondenheid (Loader 1989:430).

Wat moes die opleiding in Transvaal behels? Loader sê dit sou on-Stellenbosch, dus on-Kaaps en 'on-gereformeerd' moes wees. Dit sou ook afwysend moes staan teenoor die bevindelikheid van die piëtistiese tendens wat gedurende die periode van die kerkvereniging met die gereformeerde karakter van die Kaapse Kerk geassosieer is. Al dié behoeftes van 'n Hervormde teologie soos bedryf aan die Fakulteit te Pretoria, was volgens Loader verkrygbaar uit die derde opsie in Nederland en dan meer bepaald dié van die etiese teologie.

In sy mees resente artikel oor die onderwerp gee Loader (1996:566-586) aandag aan die redelik ernstige meningsverskille wat die laaste paar jaar die teologiese debat in 
die Hervormde Kerk gekenmerk het (hier word doelbewus liewer van meningsverskille gepraat as van ' $n$ twis soos Loader doen). Hy voer aan dat daar in die huidige debat/ (twis) by verteenwoordigers aan weerskante (o a bv Pont \& Van Aarde) 'n proposisionele waarheidsbegrip aan die lig tree. Omdat hy cordeel dat die huidige debat veral rondom die waarheidsvraag sentreer, skets hy nogeens die etiese teologie se waarheidsopvatting en lewer 'n kragtige pleidooi dat dié Hervormde tradisie, lank verwaarloos en onderbeklemtoon, steeds as derde op-sie helend op die huidige beklemmende situasie in die Hervormde Kerk kan inwerk.

Dit word hier voorlopig gestel dat Loader in sy beoordeling van die etiese teologie enkele oordeelsfoute begaan het of ten minste die etiese teologie te onkrities, eensydig positief waardeer het, en in elk geval die invloed daarvan op die Hervormde teologiebeoefening in Suid-Afrika oorskat en oorspan het. Dit is 'n vreemde gedagte dat die Transvaalse Hervormers met hulle afkerigheid van die Kaapse metodisme, piëtisme en bevindelikheid, hulle tot 'n Nederlandse opsie sou wend waar dieselfde gees geheers het. En dit bly opmerklik dat in die felle kerklike stryd gedurende die laaste helfte van die negentiende eeu in Nederland en veral rondom die doleansie, daar eintlik nooit die name van etiese teoloë figureer nie.

Dit was Hoedemaker, later gesteun deur Gunning, wat die nood van die kerk gepeil en gediagnoseer het en met hartstog, kompromieloos, partyloos vir die herstel van die Kerk gestry het.

\section{VRAE, ONDUIDELIKHEDE EN TEENSTRYDIGHEDE RONDOM DIE ETIESE TEOLOGIE}

Loader is volkome korrek in sy oordeel dat die etiese rigting 'n derde opsie gebied het tussen modernisme aan die een kant en gereformeerde ortodoksie aan die ander kant. Rasker (1974:233) skryf daaroor:

In zekere zin kan men de etischen rekenen tot wat in Duitsland de Vermittlungstheologie genoemd wordt, inzoverre zij zich naar links onderscheidden van het modernisme, naar rechts van het confessionalisme terwijl de interesse van links: de confrontasie met de door het moderne denken en cultuurleven gestelde problemen hun evenzeer ter harte ging als de interesse van rechts: erkenning van het gezag der Schrift en gebondenheid aan het belijden van de vaderen. 
Hy is ook volkome korrek dat dit eie was en is aan die teologie van die Hervormde Kerk om hom konsekwent in albei rigtings af te grens. Wat bevraag word, is of dié karaktertrek van Hervormde teologie juis 'n nalatenskap van die etiese teologie is. Dit is jammer dat Loader nooit die invloed van die ander derde of dan wel 'n vierde opsie wat in Nederland beskikbaar was, oorweeg of verreken nie. Die konfessionele rigting het immers ewe sterk en dalk selfs baie sterker teen sowel Kuyper as die modernes afgegrens. Spruit die terughoudendheid by teoloë in die Hervormde Kerk om invloed van konfessionele kant te erken dalk uit die persepsie dat die konfessionele rigting maklik in konfessionalisme verval, fundamentalisties is en in navolging van Hoedemaker die historiese kritiek verwerp het? Op die verdenking teen die konfessionele rigting sal in 'n opvolgartikel teruggekom word.

Daar is ander fasette in die denke van etiese teoloë wat vir enigeen wat tuis voel in die Hervormde teologiese denkwêreld aantreklik is. So byvoorbeeld hulle verset teen sisteemontwerp en pogings om die waarheid in formulerings vas te vang en diensbaar te maak. Dieselfde verset teen sisteem- en belydenisdwang word egter in die konfessionele rigting gevind; ook 'n verset teen reglynigheid en fundamentalisme. Rasker (1974:258) skryf van Hoedemaker:

Men kan zeggen, dat Hoedemaker veel minder kind van de negentiende eeuw geweest is dan Kuyper. Dit gaf hem enerzijds een positie die minder tijdgebonden was, anderzijds maakte het dat hij bij zijn tijdgenooten weinig weerklank vond, een onbegrepen denker bleef, omdat men in actuele vragen van kerk, maatschappij en politiek geen duidelijk antwoord van hem kreeg. Dat Kuyper zulke antwoorden wel gaf, was in zijn tijd en situasie zijn kracht; ... In later jaren zou de geduldiger visie van Hoedemaker tegenover die van Kuyper opnieuw betekenis krijgen.

Maar daar is rondom die etiese teologie ook vraekomplekse rondom 'n paar sake wat aanname van Loader se visie bemoeilik. Die eerste raak juis die kerntese van die etici: die waarheid is eties. Rasker (1974:131) skryf:

In het voorgaande kwam herhaaldelijk het adjectief etisch voor als nadere aanduiding van theologische waarheden, bv in de leer aangaande God, de Logos, de vlees wording des Woords, de Heilige Schrift. Aan deze term, die karakteristiek is voor De la Saussaye ontleent de ethische theologie haar naam. Toch is allerminst duidelijk wat de uitdrukking de waarheid is etisch, betekent. 
Dan haal Rasker Noordmans aan wat gesê het: 'Deze formule heeft iets van het raadsel van die Sphinx, aan kerkelijk Nederland in de laatste helft van de 19e eeuw opgegeven'.

Soms, sê Rasker (1974:132) wek die gebruik van die term eties die indruk dat so iets soos sedelik bedoel word, in die sin van praktiese toepassing van die leer in die lewenswerklikheid. By Beets byvoorbeeld het dié struktuur bly domineer. By De la Saussaye het die begrip verder ontwikkel. Die godsdienstige waarheid is vir hom nie net ' $n$ term wat eties toegepas kan word nie; dit is in sy wese eties. Vir die mens wat dit leer ken, het dit die karakter van 'n ontmoeting. Dit raak die mens in die geheel van sy persoon-wees. Hy kan nie objektiverend oor die waarheid dink nie, maar alleen gehoorsaam of ongehoorsaam wees.

Met dié siening van De la Saussaye, soos met instemming weergegee deur Loader, sal daar onder Hervormde teoloë algemene instemming wees; so ook die siening dat die waarheid nie in proposisies vasgevang kan word nie. Origens bly die uitdrukking: die waarheid is eties in 'n groot mate onduidelik en verwarrend. Baie min het verstaan of saamgestem wat daarmee bedoel word, soos uit die aanhalings van Rasker en Noordmans blyk. Dié kerngedagte van die etiese teologie het ook 'n vlag geword waaronder baie vreemde ladings gevaar het: subjektiwisme, indiwidualisme, piëtisme, metodisme. Die begrip eties, sê Rasker, hang saam met 'n voorliefde vir die gebruik van die begrippe gewete, persoon, persoonlikheid, bekering, wedergeboorte waarin De la Saussaye sr, eerste groot grondlegger van die etiese teologie, se verwantskap met Alexander Vinet duidelik uitkom (Rasker 1974:131). Van Zyl (1974:187) was dus nie so verkeerd toe hy oor Greyvenstein geskryf het:

Hy was miskien die mees sprekende verpersoonliking van die lewensideaal van die teologiese rigting waartoe hy saam met die twee ander ouer lede van die fakulteit behoort het, nl die ou etiesie, wat in die gees van Ritschl die klem laat val het op die opbou van die sedelike persoonlikheid.

Hier moet by wyse van kort ekskurs ook aandag gegee word aan J H Koekemoer (1994:21) se opmerking dat dit na 'n logiese afleiding lyk dat die invloed van die etiese teologie die pad na die dialektiese teologie en die eksistensiële benadering in die teologie oopgemaak het. Loader (1996:583) het in dié verband heelwat verder gegaan as Koekemoer en meer uitgebreid oor dié saak geskryf. In aansluiting by Stam uit die jaar 1951 betoog hy dat daar 'n natuurlike ontwikkelingslyn van die etiese teologie na Barth 
se dialektiese teologie is (Loader 1996:583). Die dialektiese opvatting dat die begrippe 'Skrif' en 'verkondiging' eers deur die werking van die Heilige Gees God se Woord word, is goed verbindbaar met die etiese opvatting dat die Openbaring nie in begrippe nie, maar in Christus self lê, terwyl die begrippe van die Skrif en verkondiging eers kragtens die ontmoeting met God waar is. Loader wil die ooreenkoms nie oorspan of beweer dat die etiese teologie 'n soort proto-dialektiese teologie is nie. Wat hy wel wil beweer, is dat ' $n$ affiniteit vir die dialektiese teologie verwag moet word in 'n tradisie wat etiese invloed ondergaan het. Dit geld van die Hervormde tradisie, nie toevallig dié tradisie in Suid-Afrika wat tot vandag toe die stempel van die dialektiese teologie dra nie.

Loader sê die beste getuienis vir sy betoog is die besinning van Emil Brunner oor dieselfde onderwerp. Hy verwys na Brunner se werk, Warheit als Begegnung, waarin Brunner sy besinning van jare oor 'n verantwoorde Protestantse waarheidsbeskouing weergee. Asof deur 'n etiese teoloog geskryf, bevat die titel van die boek, waarheid as ontmoeting, woordeliks die kensketsing van die etiese waarheidsopvatting. Dié boek was jare lank aan die Hervormde fakulteit voorgeskryf en is 'n bestryding van wat die etici bestry het, naamlik ' $n$ geobjektiveerde waarheid wat in proposisies bestaan.

Met die opvatting van Brunner oor waarheid as ontmoeting sal daar vanuit Hervormde kringe baie min verskil wees. Dit is deel van ons teologie. Wat betwis word, is dat dit via die etiese teologie tot die dialektiese en 'n Hervormde teologie in SuidAfrika gekom het. Daar is ernstige twyfel of daar enigsins sprake kan wees van 'n verband of ontwikkelingslyn tussen die etiese rigting en die dialektiese teologie. Daar sal aangevoer word dat die skerp invloed van Schleiermacher en die filosofie op die etiese teologie asook die sterk sintesedrang wat kenmerk was van dié rigting, die gedagte aan so ' $n$ verband of ontwikkelingslyn afsny.

Die dialektiese teologie met sy radikale beklemtoning van die afstand tussen die gans-andere, heilige God en die verganklike, sondige mens het juis krisis beteken vir al die negentiende-eeuse denkbeelde oor kontinuiteit tussen God en mens en veral die etiese rigting se drang na sintese tussen godsdiens en wysbegeerte, geloof en kultuur. Daar is ' $n$ onoplosbare teenstrydigheid tussen die sintesedenke van die etiese rigting en die spanningsvolle in die God-mensverhouding soos uitgedruk in die paradokse karakter van die dialektiese teologie. Tot sover die ekskurs.

Haitjema (1953:50) se kritiek oor Chantepie de la Saussaye se etiese teologie sny baie diep. Hy skryf:

Een religieus denker, die het Christendom zo synthetisch wil zien als een verzoening van wijsbegeerte en godsdienst, moet er natuurlijk toe komen al zijn fundamentele categorieën dubbelzinnig te maken. De begrippen 
etisch, geweten, Woord Gods - ze zijn alle bij la Saussaye van zulk een vulling, dat wij daarin twee beken, die zijn samengevloeid, kunnen onderkennen; die van wijsbegeerte en godsdienst, van etisch bewustzijn en existentiële geloofsgehoorzaamheid ... zelfs in de leerredenen van la Saussaye blijft het dubbelzinnige van al zijn fundamentele begrippen niet verborgen.

Haitjema stel dat in die opvatting van die etiese, die prakties-sedelike, die gewete en die indiwidualiteit tref ons by De la Saussaye dieselfde tweeslagtigheid aan as wat in die geskrifte van Alexander Vinet so sterk aan die dag tree. Vinet het op die religieuse denke van De la Saussaye groot invloed gehad.

Gunning jr het 'n heel uitsonderlike posisie onder die vroeë geslag etiese teoloë ingeneem. Saam met Chantepie de la Saussaye word hy allerweë erken as grondlegger van die etiese teologie. In sy latere lewe het hy baie duidelik 'n ontwikkeling deurgegaan, weg van die etiese rigting en meer na die kant van Hoedemaker en die konfessionele teologie. Dit is gestimuleer deur toenadering tussen Hoedemaker en Gunning in die gemeenskaplike stryd vir kerkherstel. Uit Gunning se eie woorde asook sy hele houding tydens die proses word die indruk verder versterk dat daar in die etiese teologie gedagtekomplekse en nuanses geleef het wat wesensvreemd is aan die BybelsReformatoriese teologie soos wat dit van die begin af en tot op die hede in die Nederduitsch Hervormde Kerk beoefen is; afgesien van baie raakpunte soos die opvatting oor waarheid as ontmoeting, die afweer teen sowel dogmatisme as modernisme, asook vrymoedige gebruik van die historiese kritiek.

Duideliker selfs as by De la Saussaye sr kom by Gunning na vore wat met die etiese karakter van die waarheid bedoel word. Dit beteken nie net dat die waarheid 'n leer is wat eties toegepas kan word nie. Die waarheid is in sy wese eties. Dit het die karakter van 'n ontmoeting, die ontmoeting van die sondige mens met die heilige God. Daarom kan hy nie objektiverend oor God dink nie. 'Met Calvijn zeggen wij dat onze idee van God etisch is, d.i. dat wij van God niet kunnen kennen wie Hij is, maar hoedanig Hij voor ons is' (Rasker 1997:144).

Teenoor God word die mens gestel voor die keuse tussen gehoorsaamheid en ongehoorsaamheid. In die waarheid wat eties is, gaan dit om bekering, wedergeboorte, heiliging. Tog kom ook by Gunning sterk subjektiwistiese trekke voor. Balke (1985: 25) bevestig dit as hy skryf: 'Dacht D Chantepie de la Saussaye individualistisch ... Gunning sprak vanaf zijn eerste optreden over het geloof der gemeente en de eenheid der kerk, al valt hij daarin niet vrij te pleiten van subjectivistischen trekken, die tenslotte Hoedemaker hem leerde uitzuiveren. 
Soos voorheen reeds gemeld, is ook by Gunning die indruk baie sterk dat onder die beklemtoning van die etiese karakter van die waarheid, allerlei ander en vreemde idees verskuil lê; so byvoorbeeld sy aanhoudende beklemtoning van die ontwikkeling van geheiligde persoonlikhede. 'De enige weg is: vrije onbelemmerde ontwikkeling van de eigen vrije, alleen aan het eigen geweten gebonden, persoonlijkheid' (Balke 1985:33).

Soos wat die toenadering tussen Hoedemaker en Gunning gevorder het, het Gunning se oë al meer oopgegaan vir die nood waarin die Kerk verkeer het. Balke (1985: 137), wat die persoon en teologie van Gunning baie hoog aanslaan, skryf:

Hier begint de kloof tussen Gunning en zijn eigen geestverwanten zich af te tekenen, die met erkenning van de hoge en door en door etische geest waarin Gunning het kerkelijk vraagstuk bespreekt, hem in zijn verlangen naar reorganisatie niet konden volgen, bevangen als zij waren in individualistische vroomheid.

Gunning het mettertyd al meer krities geraak teen vroeëre geesgenote in die etiese rigting. So skryf hy in 1898 aan Hoedemaker dat hy saam met hom glo dat die dualisme van Valeton, Wildeboer en Zeydner op die duur onhoudbaar is (Balke 1985: 145).

Kromsigt, self skrander teoloog uit konfessionele kring en 'n man wat na bewering nooit ' $n$ professoraat ontvang het nie omdat hy nie tot of die modernes of die etici (die twee groepe uit wie al die hoogleraars in dié tyd getel het) behoort het nie, was in dié dae 'n sterk medestryder van Hoedemaker vir kerkherstel. In 1897 lewer hy repliek op 'n indrukwekkende lesing van Gunning onder die titel: Hooger dan de Kerk (Balke 1985:144). Kromsicht maak met waardering melding van die feit dat Gunning in die laaste tyd al sterker in opposisie kom teen die oorgeestelikheid, gees sonder vorm, siel sonder liggaam, vroomheid sonder cortuiging; 'n gevaar, skryf Kromsigt, wat al groter word in die vroom kringe wat sy oorspronge het uit die Réveil en al meer neig in die rigting van die metodistiese en louter-etiese in die gees van Ritschl. Dis verblydend, skryf Kromsigt, dat Gunning al meer en al kragtiger vir die reg van die kerk en die betekenis van die ampte opkom. Hy spreek nogeens die hoop uit dat Gunning uit die indiwidualistiese, subjektiwistiese en oorgeestelike waters sal uitkom, om egte medestryder te word vir 'n eg-gereformeerde, presbiteriaanse kerkinrigting.

Gunning se toenadering tot Hoedemaker het onder die etici skerp reaksies ontlok. By geleentheid kla Gunning oor dié reaksies van die jongere etiese teoloë. Balke (1985:163) haal hom aan: 
Velen van mijn vrienden ... betreuren dat ik in de laatste jaren een weg volg, minder geestelijk, menen ze dan vroeger. Ter kwader ure is mijn aandacht gevallen op de kerk en haar inrichting, en heeft zich afgewend van de hoofdzaak die vroeger mijn hart had, het geestelijke leven, het inwendige.

Gunning vervolg en ontken dat hy sogenaamd konfessioneel geword het. Hy is volstrek dieselfde as vroeër. Al wat gebeur het, is dat sy oë oopgegaan het vir 'n sonde waarin hy, meer as andere versonke was: die indiwidualistiese subjektiwisme wat hom die nood van die kerk nie aantrek nie. En oor sy houding ten opsigte van die belydenis skryf hy:

Doch daar ik deze confessie verfoei (hy verwys na die kerkinrigting van 1816/52 - DJCvW), als in beginsel de Christus der Heilige Schriften loochenende, ben ik om den wille van Christus tot de gelding van onze confessie teruggekeerd, namelijk omdat de confessie de historische vorm is onderwelke de Christus onder ons is beleden, en men dus, wil men in waarheid de Christus als hoofd der kerk eren, voor onze kerk tot onze confessie terug moet.

(Balke 1985:163)

Dit is in sy eie woorde 'n erkenning van Gunning dat hy saam met baie ander in die etiese rigting verval het in 'n onhoudbare vorm van teologiese subjektiwisme waar hulle net geïnteresseerd was in die ontwikkeling van die geestelike vroomheid en lewe terwyl die nood van die kerk by hulle verbygegaan het; ook 'n erkenning dat hy in dié tyd nie die regte houding teenoor die kerk se belydenis gehad het nie, al wou hy nooit erken dat daar by hom 'n koerswending in konfessionele rigting plaasgevind het nie. Loader (1989:421) noem Gunning (jr) etiese teoloog par excellence, maar gee geen aandag aan die ontwikkeling weg van die etiese teologie af wat duidelik by hom na vore getree het nie.

Haijtema (1953:82) oordeel dat die indiwidualisme by die jonger geslag etiese teoloë, veral P D Chantepie de la Saussaye, seun van D Chantepie de la Saussaye, nog verder ontwikkel het as by die ouer geslag. 'Het individualisme van de jongere etische theologie rondom een figuur als die van la Saussaye jr, dat is, wat Hoedemaker terecht gesignaleerd heeft als een wegdwalen van Schleiermachers sociologische waardering der Kerk' (Haitjema 1953:83). 
Samevattend kan gestel word: Dat die uitdrukking: 'die waarheid is eties' iets wou sê oor die etiese rigting in Nederland se waarheidsbegrip, lyk seker. Dat die opvatting oor waarheid, naamlik dat dit geleer word in die ontmoeting met God, kenmerkend is van die Hervormde Kerk se waarheidsbeskouing, is ook korrek. Maar die konklusie van Loader dat dit via die etiese teologie gekom het, word betwyfel. Sou dit ook waar wees, is die verdere konklusies oor sterk invloed van die etiese rigting in ons eie teologie wat daarop gebou word, twyfelagtig. Dit kom voor of vir baie min verteenwoordigers uit die etiese rigting self dit werklik oor die waarheidsbeskouing gegaan het. Onder dié vlag het baie vreemde goed saamgevaar: subjektiwisme, indiwidualisme en soos nog sal blyk, sintesedrang, filosofie, onkerksheid; alles teologiese familietrekke wat wesensvreemd is aan die Hervormde Kerk en sy teologie. Daar staan 'n woord opgeteken (Haitjema 1953: 225) van Isaac van Dyk, self 'n etiese teoloog, dat in die etiese teologie elkeen minsaam vir homself praat!

'n Tweede faset van die teologie en denke van etiese teoloë waar rondom gewigtige vrae opkom, is dié rondom die kerk, gesindheid teenoor die kerk en die nood van die kerk in dié tyd. Mens kry tog snuf in die neus dat hier iets geskort het. Die uitsprake rondom Gunning se ontwikkelingsgang het dit reeds bevestig. Vir baie van dié teoloë het dit veral gegaan oor die ontwikkeling van sedelik hoogstaande persoonlikhede, die eie innerlike geestelike lewe, met min aandag en liefde vir die kerk.

Balke (1985:20) haal 'n woord van Gunning self aan uit 1894 waarin hy skerp uitvaar teenoor Valeton en ander mede etiese teoloë wat veilig en warm in hulle studeerkamers sit, hulle self ver verhewe ag bo die lastige gedwarrel van kerklike stof, en, verdiep in interessante ondersoeke, hulle nie eers verwerdig om ja of nee te antwoord op die brandende kwessie of die in puin sinkende kerk hom ook deur 'n eie, geheel selfstandige fakulteit en teologie moet laat besiel of anders ten gronde gaan nie.

Kromsigt verwys waarderend na Gunning se wegbeweeg van die etici se oorgeestelikheid en stel dan: 'Een gevolg meer in het bijzonder van het laatste is, dat Prof Gunning in tegenstelling met de in etische kringen doorgaans heersende onkerkelijkheid een steeds kragtiger kerkelijke toon aanslaat, als wij het zo eens noemen mogen (Balke 1985:144). Balke (1985:244) maak self in dié verband 'n belangrike opmerking. Hy spreek waardering uit dat Gunning wat onder Opzoomer studeer het, nooit voor dié se modernisme geswig het nie maar dat die kruis van Christus sentraal gebly het in sy denke. Dan vervolg hy: 'Daarbij is er bij Gunning steeds een hartstochtelijk verlangen naar de gemeenschap van de kerk geweest en daarin onderscheidt hij zich zeer bepaald van Chantepie de la Saussaye'. 
De la Saussaye sr het in sy dogmatiese besinning die begrippe kerk en gemeente skerp uitmekaar gehou. Hy lê sterk klem op die geloof van die gemeente, die gemeenskap van die gelowiges. Haitjema (1953:62) speur daarin sterk invloed van die DuitsLutherse Vermittlungs Theologie. By die Lutherse kerkbegrip het die etiese indiwidualisme van De la Saussaye, wat die gelowige persoonlikheid as enkeling uitgangspunt van elke geloofsgemeenskap wou maak, die maklikste aansluiting gevind. Daarteenoor stel Haitjema dat die teologie van die jonger etiese teoloë, in elk geval De la Saussaye jr en sy geesgenote, nog baie meer indiwidualisties geword het. Vir die geloof van die gemeente is hier nie meer veel gevoel nie. Primêr is vir De la Saussaye jr resloos die persoonlike verhouding tot God. Dit word uit God se direkte innerlike openbaring gebore en stel die mens eers volkome eensaam. Eers daarna kom die vraag aan die orde hoe hierdie allerpersoonlikste geloof hom sal uitwerk in die verskillende kringe in die gemeenskap - waartoe volgens hom dan ook die kerk behoort. So word die kerk by De la Saussaye 'n periferiese saak waarmee die Christen in aanraking kom wanneer sy persoonlike verloste lewe tot ontvouing kom. Die kerk is immers een van die gemeenskapskringe waarin die gelowige moes teregkom. Die indiwiduele lewe is primêr; die lewe in die gemeenskapskringe is wat daarna kom. In dié gemeeskapskringe staan die kerk naas familie, staat, maatskappy, mensheid.

\begin{abstract}
De wijze, waarop la Saussaye over de vulgariteit der kerkse Christenen spreekt, laat voorts duidelijk merken, dat hij innige simpathie gevoelt met die schöne seelen, die ver van het kerkelijk Christendom blijven, ook al zijn ze niet a-religieus, en dat hij zelf ook niet weinig aversie heeft te overwinnen gehad, om toch im Grossen und Ganzen een kerkelijk Christen te blijven.
\end{abstract}

(Haitjema 1953:101)

Hierdie gedagtewêreld rondom die kerk is ver verwyder en wesensvreemd van wat in die Bybels-Reformatoriese teologie oor die kerk geglo en bely word. Ons voel ons self baie nader aan en verwant met ' $n$ Hoedemaker en sy hartstog en liefde vir die kerk, die liggaam van Christus, sy reg en sy welwees en - as hy dan in verval raak, sy herstel en weer gesond word.

Dit bring ons by die laaste vraekompleks rondom die etiese teologie wat hier behandel word, naamlik die invloed van die filosofie en die drang na sintese in dié rigting. Uit hierdie besinning sal blyk dat dit uiters problematies indien nie onmoontlik is nie om enige verbindings- of ontwikkelingslyne of verwantskap tussen die etiese teologie en die dialektiese teologie te lê. 
P D Chantepie de la Saussaye, seun van Daniël Chantepie de la Saussaye is in 1878 aangestel as eerste hoogleraar in algemene godsdienswetenskap in Amsterdam. Hy word algemeen erken as behorende tot die jonger of dan die tweede geslag etiese teoloë. Hy aanvaar dat ook die nie-Christelike godsdienste op openbaring berus (Rasker 1974:235). Aan die behoefte van die menslike gees kom dieselfde God oral tegemoet. Hy openbaar Homself in natuur en geskiedenis, in rede en gewete. Die oorspronklike openbaring moet ons nie in die geskiedenis soek nie maar liewer op die bodem van die menslike hart. Anders sou die heidense religieë as verbasterde vorm daarvan beskou moes word. Die oneindige is oral. Die lewende God is nêrens ver van dié mens af wat Hom, al ken hy Hom nie, tog dien. Rasker haal De la Saussaye aan: 'Omdat ik in het christendom de waarheid erken, kan ik onmogelijk eenigen godsdienst voor ijdel houden' (1974:235).

Ons is hier ver verwyder van Karl Barth se siening dat die openbaring in Jesus Christus oordeel en krisis vir alle godsdiens beteken, ook die Christelike; 'n siening wat die teologiese houding ten opsigte van openbaring en godsdiens in die Hervormde Kerk diepgaande beïnvloed het. Maar die verskil met die dialektiese teologie sny nog dieper. Sintetiese denke was nie kenmerkend van Karl Barth se teologie nie, miskien in 'n mate wel van die latere Brunner en andere. Rasker, hoogleraar vanweë die Nederlandse Hervormde Kerk aan die Leidse Universiteit (1954-1974) en uitmuntende kenner van dié kerk se geskiedenis en teologiese rigtings, openbaar in sy werk sterk simpatie en aanklank met die etiese teologie. Hy ontken dat Chantepie de la Saussaye te ver orgebuig het na die kultuur soos dikwels beweer word. Nogtans erken hy dat De la Saussaye sr, net soos die Groningers, modernes en regse denkers en aktiviste, gesoek het na 'n verbinding van natuur en genade, 'n versoening van wysbegeerte en openbaringsgeloof. 'In de christologie en pneumatologie, de antropologie en de soteriologie was zijn denken meer synthetisch dan dialectisch of paradoxaal' (Rasker 1974:137).

Haitjema se oordeel oor die etiese teologie was baie negatief. Hy stel dat De la Saussaye sr aan die filosofie te veel eer toeken (Haitjema 1953:50). Dit spruit uit sy drang om die Christendom aan te bied as versoening van wysbegeerte en godsdiens. De la Saussaye, sê Haitjema, laat die filosofie uit die heidendom voortkom en stel dit dan parallel in waarde met die godsdiens van die Jode. In werklikheid het ons hier te doen met 'n gevaarlike oorskatting van die filosofie van die heidendom en 'n ewe gevaarlike depresiasie van die Ou-Testamentiese openbaring.

In De la Saussaye sr se opvatting oor die etiese, die prakties-sedelike, gewete en indiwidualiteit tref ons dieselfde tweeslagtigheid aan as wat in die geskrifte van Alexander Vinet so sterk aan die lig kom. Vinet het op die ontwikkeling van De la Saussaye se religieuse denke groot invloed uitgeoefen (Haitjema 1953:51). 
Die dubbelsinnige van al De la Saussaye se begrippe blyk veral as hy in sy leerredes handel oor die Woord en oor die etiese. Die term 'Woord van God' sê Haitjema, beteken by hom nie konsekwent die evangelie, die heilsboodskap nie; soms wel, maar tog nie altyd nie. Soms beteken sy verwysing na die Woord van God ook die sedelike bewussyn, die stem wat by niemand swyg nie, wat alleen maar in Jesus Christus versterk tot die mensekinders deurdring. Hierdie lyn, hom bygebring deur die Duitse wysbegeerte, ag hy prinsipieel versoenbaar met die ander lyn, naamlik die Woord van God as nuwe, blye boodskap (Haitjema 1953:52). Ook die begrip eties is soms sedelik bepaald in algemeen-menslike sin. Andersyds het dit weer die betekenis van lewend uit die lewendmakende Gees.

Die krag, sê Haitjema, wat die etiese teologie, indien dit by die wesenlike van sy uitgangspunt gebly het, nog kon gehad het, is verlore juis vanweë 'n te sterk drang na sintese van Christendom en kultuur. Hy sluit in sy kritiek op die etiese teologie aan by Van Niftrik wat gewys het op die onhoudbare kontinuïteit tussen God en mens wat deur die etici geponeer is. 'Hier staan wij voor het uitgangspunt van alle paragrafen van het etische programma: geloof én wetenschap, Christendom én cultuur, Heilige Geest én geweten, dogmatiek én philosophie, het geloof der gemeente én de psychologie, enz' (Haitjema 1953:239).

Die etiese teologie is uit die réveil gebore en het ryke belofte vertoon. Deur die drang na sintese, soos veral speurbaar by De la Saussaye sr, is die teenstellinge van die oorspronklike réveil egter in newestellinge verander en die groot teenstelling tussen Aufklärung en Réveil, Reformasie en rewolusie afgeplat (Haitjema 1953:47). Haitjema sê die werklike rede waarom die etiese teologie alle krag, invloed en aktualiteit verloor het, is omdat dit só onderhorig was aan wysgerige vooronderstellings dat dit saam met die heersende filosofie van 'n bepaalde tydsgewrig gedoem was om te verouder en te vergaan. Terwyl die ouere etici sterk beïnvloed is deur Schleiermacher, Ritschl en Vinet, het die jonger geslag, wat uitgangspunt en vooronderstelling betref, hulle gewonne gegee aan die Romantiek en veral aan die nieu-Kantiaanse filosofie en wetenskapsleer. Dit het by De la Saussaye jr daartoe gelei dat, anders as by sy vader en Gunning, indiwidualiteit en persoonlike vroomheid eerste gestel is; Woord en leer is sekondêr. By Valeton het dit gelei tot teologiese agnostisisme (Haitjema 1953:224240).

In die lig van die voorafgaande is dit moeilik om enige verband of ontwikkelingslyn tussen die etiese rigting en die dialektiese teologie te aanvaar. Vir dié aanname bestaan daar wesenlik geen gronde nie. Dit wil voorkom of die enigste rede vir so ' $n$ aanname die ooreenkoms in klank is tussen die etiese teologie se kerngedagte, 
naamlik dat die waarheid eties is (en wat sommige daaronder verstaan het) en die gedagtes van Emil Brunner oor waarheid as ontmoeting.

Haitjema (1953:84) sê daar is weinig gegewens wat laat vermoed dat De la Saussaye jr gunstig op die dialektiese teologie sou gereageer het. Haitjema (1953:198) beweer ook dat vrysinnige sowel as etiese teoloë later (na die breuk tussen Barth en Brunner) by verre voorkeur gegee het aan die Brunneriaanse vorm van dialektiese teologie bo dié van Barth. Daarby het die dialektiese teologie, en dan veral dié van Barth, baie diep ingewerk op die konfessionele rigting asook dié van die Gereformeerde Bond in die Nederlandse Hervormde Kerk.

Dit sou 'n meer verantwoorde siening wees om daaraan vas te hou dat die dialektiese teologie van Barth (en Brunner in sy vroeë fase) 'n prinsipiële verset teen die bevinding en vroom mistiek van die nieu-Protestantse teologie van die negentiende eeu in die gees van Schleiermacher was en waarvan die etiese teologie in Nederland onherroeplik 'n deel uitgemaak het.

\section{SAMEVATTING EN FINALE KONKLUSIE}

Hier word volstaan met die konkluderende opmerkings waartoe telkens in die voorafgaande betoog reeds gekom is: Dat hoewel daar op die klank af soms sterk ooreenkomste tussen die etiese rigting en die teologie soos in die teologiese opleiding aan die Universiteit van Pretoria (Afd A) en Hervormde kerklike kringe beoefen, vermoed kan word, die etiese teologie tog wesensvreemd is aan die Nederduitsch Hervormde Kerk se teologiese inhoude, klimaat en gedagtewêreld.

Loader kyk dit mis of voel dit nie aan nie. Sy beklemtoning van die invloed van die etiese teologie kom geforseerd en eensydig voor. Die etiese rigting het ook nie, soos Loader en ook ander beweer, aan invloed en bekendheid getaan omdat dit deel van ons teologiese denke geword het, of vanweë die wyd-geskakeerdheid en daarom moeilik-definieerbaarheid daarvan nie. Die werklike rede vir dié verlies aan verdere invloed was dat dit só met wysgerige strominge geïdentifiseer het, dat dit gedoem was om saam met dié strominge te verdwyn.

Daar sal in 'n opvolgartikel gekyk word na die baie sterker en meer oortuigender invloed wat van die konfessionele rigting en van Hoedemaker uitgegaan het. Dit het aan die Transvaalse Hervormers en hulle teologiese opleiding 'n ander opsie as die etiese voorsien vir hulle soeke na 'n teologiese pad weg van sowel die moderne as die gereformeerde invloed.

Hier word doelbewus gepraat van die konfessionele rigting en Hoedemaker omdat Hoedemaker hom na aanvanklike betrokkenheid by die konfessioneles spoedig van hulle losmaak. Hy het by sommige van hulle dieselfde tekens van partysug as by 
Kuyper opgemerk en waarvan hy so 'n intense afkeer gehad het. Haitjema vind by die nakroos van Hoedemaker en die konfessionele rigting sterk familietrekke wat ondanks spanning en verskille die onderlinge eenheid behou het.

Confessionelen willen Hervormd zijn tegenover de separatie-tendenties, die in Kuyper's strategisch program voor de reformatie der Kerken scholen; en tegenover de liberalistische vervlakking, die het begrip Hervormd uitspannen wil over een kerk van 'vrije vroomheid', waarin heel het volk zich tuis voelen kan ... (Haitjema 1953:263).

Haitjema sluit ook aan by Berkhof wat oor die geestelike familietrekke van Hoedemaker en die konfessioneles geskryf het:

... het meer origineel-Gereformeerde type, dat, weinig beïnvloed door het piëtistisch-subjectivisme, en wars van de neo-calvinistische opsplitsing van Nederland in een aantal volksdelen, de rechtvaardiging door het geloof sterk accentueerde, een reorganisatie van heel de Hervormde Kerk (dus geen afscheiding) voorstond, en pleitte voor een overheid, die de Schrift als norm van haar handelen zou aanvaarden en de gereformeerde confessie zou bevorderen.

(Haitjema 1953:263)

Hiermee is ons waarskynlik baie nader aan die hart van Hervormde teologie en kerkwees in Suid-Afrika as wat ooit in die dampkring van die etici gevoel kan word.

\section{Literatuurverwysings}

Balke, W 1985. Gunning en Hoedemaker samen op weg. s' Gravenhage: Boekencentrum.

Breytenbach, A P B 1992. Egge Simon Mulder, hoogleraar 1956-1970. HTS 48/1 \& 2, 101-112.

Haitjema, ThL 1953. De richtingen in de Nederlandse Hervormde Kerk. Wageningen: $\mathrm{H}$ Veenman \& zonen.

Koekemoer, J H 1994. Die idioom van die Nederduitsch Hervormde Kerk: 'n Teologiese vraag. HTS 50/1 \& 2, 14-26. 
Loader, J A 1984. Die etiese Ou-Testamentici in Nederland tussen 1870 en 1914. D Th-proefskrif, Universiteit van Suid-Afrika.

1987. Tertium datur: Oor die etiese waarheidsbegrip. HTS 43, 47-56.

1989. Ontstaan en eerste periode van die Hervormde Teologiese Opleiding aan die Universiteit van Pretoria. HTS 45, 412-437. 1996. 'n Hervormde tradisie as heelmiddel. HTS 52, 566-589.

Oberholzer, J P 1992. Terugblikke op die Fakulteit Teologie (Afd A), Universiteit van Pretoria, en sy lede: 'n Literatuurverkenning. HTS 48, 575-584.

Pont, A D 1994. Historiese perspektiewe op die kerklik-teologiese opleiding van die Nederduitsch Hervormde Kerk aan die Universiteit van Pretoria. HTS 50/1 \& 2, 95-110.

Rasker, A J 1974. De Nederlandse Hervormde Kerk vanaf 1795. Kampen: Kok.

Rautenbach, C H 1974. Vyftig jaar byderwetse Bybelwetenskap. Gedenkalbum 50 Van der Hoff Teologiese Vereniging 1924-1974, 24-34.

Van Zyl, F J 1974. 'n Blik op die lede van die ou Fakulteit. HTS 30, 183-190. 